\title{
Corporate social responsibility: Why bother?
}

\author{
Lars Isaksson, Tim Kiessling, Michael Harvey
}

Corporate Social Responsibility (CSR) is not a new concept, but unfortunately has been defined in so many ways, it is often misinterpreted. In fact it has had 40 years to evolve from a somewhat infant concept to a successful managerial tool to build a company's reputation in the global market arena. Corporate social responsibility has become corporate strategic responsibility - an imperative element of corporate global business strategies. Many leaders, entrepreneurs, investors, executives and politicians now recognize CSR's potential for differentiation and positioning in the global marketplace. In the 21st century, we find CSR to have a remarkable acceptance among practicing managers; publicly traded corporations especially label CSR an essential tool for their long-term legitimacy and profitability. CSR has matured from its infancy, becoming a corporate reputational addingvalue strategy for firms.

\section{GLOBAL ISSUES I: PLAYING THE MARKET}

The liability-of-foreignness is a common problem for firms entering new markets. Companies expanding their operations by entering a new host country face scrutiny by local competitors and customers. Lundin Petroleum is a Swedish resource-prospecting corporation active in Africa and former Soviet Union satellite regions. Chief executive officer (CEO) Ian Lundin said in an interview that the reason they engage in CSR is that:

\footnotetext{
We view our business as not only having a permit to operate in our markets but a social license to operate. We further want to jointly understand our stakeholders to prevent misunderstandings and misperceptions. As such, we align CSR to reduce business risk, to build our reputation and to achieve a competitive advantage when governments approve our permit applications. At the end of the day, the stockholders depend on us to do the right thing short term to maximize return long term. As society evolves so do we. All business is partnerships with the society.
}

Companies like Lundin Petroleum do not engage in CSR for window-dressing purposes. They have experienced first-hand that CSR is a market force that can have both short-run and long-run consequences. By assigning a strategic status to the concept of corporate responsibility, they ascribe CSR intangible value with long-term benefits relative to their market participants (investors, employees, customers and geographical stakeholders affected by their business activities). They therefore allocate corporate resources to ensure that their CSR efforts result in win-win outcomes for the company and the market environment.

\section{GLOBAL ISSUES II: WHISTLE BLOWERS}

Recently, whistle-blowers have surfaced suggesting that some firms have been causing environmental and ethical malfeasance. Organizations like WikiLeaks have been used to unveil "wrong doings" by governments, corporations and individuals. This also fuels the need for CSR to be strategic. The recent technology race has restructured peoples' accessibility to, and usage of mobile computing. We have witnessed a radical shift in which mobile devices have shifted from mere diary and e-mail functions to becoming universal portals actively targeting social issues. The avalanche of smart phones, pen-tablets and cloud computing applications in combination with social media like FaceBook, Linkedln, YouTube etc. have not only made it extremely easy for anyone to reach millions of people in seconds with shame and blame stories of socially bad behaviors from corporations, but also generated a craving for it. People of all ages, socioeconomic backgrounds, race, religion and geography use social media to be seen, heard, accepted and possibly to provide an existential meaning. The enlightened, communicative and sometimes vitriolic consumer has been born. It is easy to envision their expectations: "throw them to the lions;" "the rich and greedy should not escape punishment;" "let's give the masses what they want." In many cases there's a sincere urge to make the world a better place, yet sometimes it is 
often just individual sensation seeking. Like digital gladiators, enlightened consumers today take on personal crusades relative to specific firms if they perceive a company as "bad" (guilty or not) in regards to its marketplace behavior.

When British Petroleum (BP) failed to safeguard their offshore drilling activities in the Gulf of Mexico, leading to the 2010 oil spill, activists in the U.K. punished BP by erecting barricades hindering motorists from refueling their cars at BP's gas stations. When the fashion company Tommy Hilfiger was exposed as keeping children in sweatshop and slave-like conditions in Burma, activists managed to hurt their sales, as consumers abandoned what they perceived as an "unethical brand." While the guilt was certain in the first case, it was not in the second. Tommy Hilfiger was innocent, as they were victimized by counterfeit operations. The sweatshop belonged to a criminal network. Sometimes corporations get the shame and blame even when they are innocent.

Regardless of existing levels of market exposure, corporations risk being targeted by activists and are therefore better off with sufficient portions of reputational armor protecting their good-standing and market legitimacy. It is better to be prepared (being credible) beforehand should the "trouble hit the fan." Even governments can be targeted. When the French secret service, DGSE, had two agents bombing and sinking the Greenpeace vessel Rainbow Warrior in Auckland, New Zealand in 1985, to protect the vessel from entering French military nuclear test zones in the South Pacific, citizens of most European countries joined the protesting activists and condemned the French government. This led to a massive boycott of French produce - mostly wines opening the market for the Australian and New Zealand wine producers. When the consumers got accustomed to the substitute wines most consumers never returned to purchase French wine. The estimated 20 percent annual drop in wine exports has not recovered since - three decades later.

\section{CSR AS A CONCEPT}

Currently CSR is a corporate behavior and management philosophy that an increasing number of corporations worldwide choose to adopt. The underlying perspective has therefore shifted toward a global perspective of strategic CSR instead of a focus on a one-country/one-issue orientation. The typical and traditional set-up of a CSR program entails a corporation contributing some set of resources (usually people or money) for a social impact outside the normal scope of the company. In simple terms, they give money to some cause that is not part of their corporate trading activities. Some corporations allow their employees to engage in some volunteer work while being paid by the employer. One such corporation is the Australian branch of PriceWaterhouseCoopers (PWC), which in 2010 joined forces with the NGO (non-governmental organization) Mission Australia to mentor young people from challenged areas in management skills. This increases the recruitment pool of future top managers within PWC, educates the youngsters participating in the program and attracts new customers. New customers specifically selected PWC as their partner due to their reputation and composition of CSR activities. Other corporations engage in the provision of clean drinking water in under-developed African villages, where the environmental improvement contributes to the wealth development of that society. Both examples can increase a company's market size in the form of new customers long-term.

Numerous corporations in Europe, the United States and in the Asia-Pacific region (for example Microsoft, BMW, SONY, Toyota, Colgate-Palmolive, IKEA, Carlsberg and LEGO) are convinced that CSR can improve their brand, their reputation and their financial performance. A study performed by PriceWaterhouseCoopers reported that as many as $70 \%$ of international CEO's believed their CSR efforts to be vital to their firm level profitability, and KPMG's 2012 report of Corporate Responsibility echoed these beliefs. The updated 21st century version of CSR: “CSR_v2.0”, provides opportunities demanding a sincere approach which in turn must be managed and implemented strategically to be valuable.

\section{STRATEGIC CSR}

CSR is used to reinforce firm corporate strategy or to gain some specific benefit in the global marketplace. The pharmaceutical corporations Glaxo-Smith Kline and Astra-Zeneca deploy CSR to support their long-term legitimacy, being dependent on animal and human in vivo research. The FMCG giant Nestle uses CSR to increase product quality and output from their suppliers by educating suppliers (farmers) in India. The firms GAP Inc. and OriFlame engage in CSR as a means to build credibility of "natural" products with as low environmental and user impact as possible. The industrial global tool company Sandvik engages in CSR to protect the group from lawsuits, litigation and to detect and fight corruption. These companies and thousands of other corporations take a longterm investment approach to CSR. They also view CSR as a means to create or increase some competitive advantage, with the ultimate effect of increasing their performance.

While executives for a long time have understood and accepted that brand image can increase firm performance, CSR now shares that role. CSR also increases a company's credibility, which along with reputation provides a form of insurance (reputational capital) in case of sub-optimal ethical behavior. When Telenor (a top ten global telecommunications company) in 2008 was targeted regarding workers' safety negligence by the European media, their share price decreased approximately 5 percent. A sub-contractor to their subsidiary in Bangladesh disregarded contractual agreements (regarding workers' safety), leading to fatal accidents around their acidic galvanization pools. The CEO, Jon Fredrik Baksaas, personally visited the factory in Bangladesh twice with his audit executives to ensure that a solid solution was reinstated, audited and managed long-term. Since Telenor had a strong CSR reputation and immediately took action to rectify the situation, the share price was restored in a few weeks to its former level. The bad press was considered "out of character" for the otherwise well reputed corporation. Their prompt action was soon positively reported in the European media and by market analysts.

Global companies are now challenged with more complex interactions and diverse interests of multiple stakeholders. It is not enough to look after customers or suppliers alone, but also those who can, might and will be affected by a corporation's operations and market activities. It therefore appears that companies need to apply a broader, more holistic market approach that extends outside traditional realms to better 
serve company objectives. In the process, firms will also act in their best interests as they engage in building tacit value and future oriented competitive advantages.

GAP Inc. has created a CSR program called P.A.C.E. (Personal Advancement and Career Enhancement Program). In this program, GAP provides their suppliers' factory workers "life and work skills education - in areas such as communications, decision-making, time and stress management, and health and nutrition - that benefit them both at home and at work." P.A.C.E has been a great success. Today more than 5000 female factory workers from six countries have participated in GAP's strategic CSR program. One of GAP's largest vendor partners in India has found this innovative program to be so beneficial that they will roll out the P.A.C.E program to their entire workforce covering 60,000 workers in 34 factories.

\section{CSR IN THE MARKETPLACE}

Customers are today increasingly more organized, more informed and more demanding than earlier generations of managers encountered. These new market pressures demand and reinforce that the companies' overall strategy should embrace and implement CSR as a core business function. Corporations today operationalize CSR with a specific strategic intention and communication resources to carefully craft and execute the CSR deliverables, such as GAP Inc's P.A.C.E program. Companies are including CSR in their strategy to obtain some specific benefit in return. At the multinational telecom company Millicom, the consulting firm PriceWaterhouseCoopers and the pharmaceutical giant Astra-Zeneca, CSR programs are said to be directly responsible for increasing the acquisition and retainment of customers.

While CSR can provide several potential opportunities, CSR cannot create these potential benefits without strategic alignment. Companies need to plan, organize, manage, implement, communicate and control CSR in the same fashion as they would any other strategic component. Companies must synchronize and align CSR with the overall companylevel objectives. For CSR to be successful, a firm needs to perform organizational adjustments, review structures of intra-departmental, and intra-stakeholder relationships and instill an incentivized support. Managers who are ignoring the CSR potential without strategic understanding of CSR might postpone or neglect valuable CSR activities, savings and investments. This can lead to extensive future costs if the company is later condemned by stakeholders for violating some socially perceived obligation.

The Australian company James-Hardie (manufacturer of fiber cement building products) systematically ignored early warnings regarding the severe health effects of asbestos, resulting in a multi-billion dollar class-action lawsuit. A more recent example is the 2010 Gulf of Mexico oil spill by the British Petroleum company BP. In Europe, offshore drilling companies are required to install mechanical locks (at $\$ 500,000$ each) which prevent blowouts should the drill pipe malfunction at the sea floor. BP successfully lobbied the U.S. Congress to exclude such precautions in the Gulf of Mexico. The initial cost savings of approximately $\$ 20$ million instead led to BP being forced to allocate more than \$20 billion to mitigate what initially was a preventable damage.
British company Lonmin, a platinum mining company and metal producer, also ignored CSR implications. When their miners in their Marikana mine, South Africa, started to strike in August 2012 for better compensation and improved workers' safety in the dangerous platinum extraction process, the company ordered the local police to break up the strikers by opening fire at them, killing 34 of their employees. At the same time their Web site reads:

We're committed to zero harm to people and the environment... and we're committed to integrity, honesty and trust, being ethical people.

Interestingly, like the case with Tommy Hilfiger, who had to protect itself from wrong doing despite being innocent, another U.K-listed miner, Anglo-American, suspended operations at its South African platinum mines one month later. The official reason was to "protect the safety of our employees" and not to risk being smudged by bad press, where media potentially assume one mining company being as bad as the other. Anglo-American wanted to stay out of trouble that easily could have transferred from one industry player to another. CSR-derived reputational capital is a new currency to be recognized and needs to be applied proactively.

\section{SYSTEMATIC CSR APPROACH}

In order to capitalize on CSR, firms must systematically analyze their current internal- and external orientation regarding their customer processes. A majority of the firms who successfully capitalize on CSR have a customer orientation aligning their daily activities (internal set-up) toward customer satisfaction, customer preferences and customer problem solving. Examples of external orientation include firms adopting a longer-term perspective monitoring changes in customer demands, adjusting their value propositions to exceed customer expectations and predicting competitor behavior. They also coordinate and address strategic CSR at the upper management level (CSR committee, TMT or Board of Directors) and prioritize regular assessment of their CSR efforts by having CSR as a fixed item on TMT meeting agendas. It is therefore recommended to adopt an openminded and genuine assessment regarding "why," "how" and "what" a particular company should include in their CSR investment before deciding "who" should be in the receiving end.

The "why" is best achieved by answering the questions "what market risks can we mitigate with a stronger corporate reputation?' or, “which opportunities can be captured with large amount of reputational capital?" The answer to the "how" question evolves around assessing what company functions and departments must be involved to resolve the answers to the "why" questions. Once there's a clear, understandable link (that also can be communicated internally) between the "why" and the "how," the corporation can progress with the specifics of a strategically designed CSR program (the "what" and the "who"). This approach overcomes a common hurdle, since the comprehension and implementation of CSR is problematic and can be an exercise in wasting valuable resources better deployed somewhere else in the worst case. The latter is often the outcome when the CSR activities are not aligned and interrelated. 
Companies considering whether to start a CSR program, or to assess current program effectiveness, would in this way find it easier to comprehend and implement it in the first place.

CSR must be built as a clear construct based on underlying reasons in relation to corporate objectives and priorities. Without a precise definition of what a firm would like to achieve with its CSR efforts, the wanted outcome will most likely not arise. It needs a thorough alignment and interrelatedness between the core business objectives and the CSR deliverables. In other words, "what" CSR activities to deliver must be built upon "why" to engage in CSR, before we can discuss "how" and for "whom" we should make the effort and allocate the necessary resources. Again, it is recommended that the CEOs and strategy executives approach corporate social responsibility (in unison with CSR managers) like any other managerial discipline (e.g. marketing, branding or R\&D). These omnipresent business activities are also typically addressed in a "why-how-whatwho" order, precisely like CSR should be addressed. It is important to focus on the strategic intent behind CSR engagement in order to provide the practicing manager aid in the enablement and operationalization of CSR.

To reap the potential benefits from using CSR, it must be aligned with the firm strategy. It is important to not just focus on historical thought that concentrated on immediate direct financial impact and performance, but to long-term benefits. The top-performing corporations start strategic CSR efforts with why should we implement CSR?" The answer to that question is likely to clarifying the strategic intent behind engaging in CSR.

\section{CSR COMMUNICATION}

Implementation of CSR should be holistic and include internal and external communication to support the corporation's strategic intent. When CSR activities are communicated and understood it can act as an insurance-like protection that yields reputational capital. In the event of any unfortunate negative actions that violate the corporate reputation, accumulated reputational capital helps to protect the corporation and makes it possible to detach the problem (for example an unethical behavior, an illegitimate action or an accident) from the rest of the organization. In this way corporations experience that the marketplace allows them time to respond to stakeholder suspicion so problem resolution can be dealt with on a process-, departmental- or even individual level without harm to the entire company. The holistic approach considers multiple related concerns. For example, a company's socially responsible purchasing criteria are likely to affect their value chain decisions.

The timing of CSR communication is also an important issue, given that timing can have a profound impact on communication goals, that is, if a firm is rewarded or punished by the market for its behavior. A corporation's attention to timing issues therefore evolves around whether the communication objective should be event driven, and if so, whether it should precede media intention (being proactive) or be released in response to media attention (a reactive approach). This makes CSR an issue that needs to be designed. It benefits from, and potentially requires, intensive communication. One way corporations leverage CSR communication is by using multiple communication tools like social media and Web sites (pull) in combination with annual reports and press-releases (push).

The Husqvarna Group (a global manufacturer of lawnmowers, garden power tools, chainsaws and off-road motorcycles), takes a standardized communication approach by following the recommendations provided by the Global Reporting Initiative Organization (GRI). GRI advocates economic, environmental and social sustainability by providing member companies and organizations with a reporting framework as part of a company's governance report. While this is a standardized approach (design), it provides a release structure where the information is typically published in annual reports (timing). Another example is Royal Dutch Shell, which relies on social media (design) in real-time (timing) communication. Shell uses multiple social media tools (YouTube, Twitter, FaceBook, Linked In, Flickr and RSS) in addition to Web site and annual reports to engage with, learn from and collaborate with individuals or groups;

Social media provides Shell the opportunity to continuously and immediately discover conversations for the purpose of enhancing and protecting the Shell reputation and brand.

Customer communication decisions include whether to be holistic, how to communicate externally, how to communicate with their employees (internal communication) and whether to communicate product related CSR information. One company with a holistic approach toward CSR initiatives and CSR communication is H\&M (the largest fast-fashion company in the world with 104,000 employees and 2900 retail stores worldwide), where Helena Helmersson, the CSR director of the H\&M board, reports that being the largest buyer of cotton in the world demands such an approach. Annual savings of more than 450 Mega liters in the denim production process (sustainability efforts), having a majority of management positions occupied by females (equality and diversity efforts) and having educated 570,000 supplier workers in Bangladesh about their worker's rights (social responsibility) has occurred. SCANIA (a global heavy trucks and bus manufacturer) is committed to continuously improving how they operate and manage their downstream impacts, defining ambitious long-term goals and cutting $\mathrm{CO} 2$ in their own use of supply chain transportation. In addition they communicate their objectives and results internally and externally in a proactive (push) and reactive (pull) fashion (design and timing). SCANIA's CEO, Kai Warn:

It's about making vehicles that are efficiently produced, cost-effective and safe to operate and, to the greatest degree possible, recyclable at the end of their life cycle.

A company that focuses on product related (specific) CSR information is DIAGEO (brand owner of Smirnoff, Johnny Walker, etc.). Since water is the most crucial ingredient in any of their products, DIAGEO is redesigning its agricultural supply chain. In Cameroon, Africa, they are engaged in the development of a grain substitute (sorghum) by working with local farmers, providing them with training and support. The sorghum grass needs less water to grow, needs less water in the brewing process and is known to improve soil quality for rotational food staples. This substitute product improves life 
conditions for the farmers (suppliers), increases the capacity of small-scale farms (increased output) and provides cost savings by sourcing locally instead of importing raw materials to the regional markets.

Corporations with high levels of CSR performance pay greater attention to the timing and design of their CSR communication. They further respond in media in a reactive and holistic fashion targeting their customers, products and employees. In summary, corporation's today use internal and external CSR communication to instill organizational identification and belonging among employees and customers. Employees report they feel more secure in their job roles and perform better, and increase the service levels to employers' CSR activities. In conclusion, strategic CSR holds the potential to entice all stakeholders, becoming an important part of corporate identity where communication is foundational to its success.

\section{CORPORATE STRATEGIC RESPONSIBILITY: RECOMMENDATIONS}

We supported our research with empirical research findings from the Top-100 Social Responsibility Index from Sweden, provided by NASDAQ-OMX and GES Investment Services covering 34 industries. Our research suggests that the top performing corporations' reasons to engage in CSR evolve around selecting a specific strategic intent. The corporations engage in CSR to increase their reputation, to reduce their market risk or to gain competitive advantages in regards to customer attraction and retention. Cost savings, being an earlier reason to engage in CSR, has instead crossed over into the sustainability arena. The following strategic intents were identified: cost reduction benefits; risk reduction benefits; strengthened reputation or other types of competitive advantage gains (for example increased employee motivation or above industry average sales performance).

Corporations with a strategic CSR intent also engaged in more CSR activities and had better financial performance. Examples of companies with high CSR and high performance include ABB (industrial equipment), Ericsson (telecom), Swedbank (commercial banking) and Electrolux (household durables/white-goods), while companies with weaker CSR performance (lower ranking) include Intrum Justitia (debt collecting/outsourcing), Loomis (security services) and Kinnevik (a multi-industry investment company). A specific example among the participating companies (given that the majority engaged in CSR to build their reputation) is AF-Consulting. AF is a major market-leading Nordic energy and utility consultancy company. The CSR manager, Alice Bah-Kunke, claimed their long-term investments in CSRderived reputation led to attracting better talented employees (without paying higher than industry average salaries), led to faster recruitment process completion than prior to their CSR undertakings, and that the CSR reputation aided in staff retention, creating a strong esprit de corps. They attributed their competitive advantage of having the most competent consultant engingeers to their reputation.

The importance these companies allocate to their CSR efforts was also manifested in CSR related decision-making.
The CSR executives did not solely have the decision-making authority, despite being executives (CSR is mostly an uppermanagement or an executive task in 67 percent of the companies). Only one-third of these executives had autonomous decision rights. The majority of CSR decisions were instead made by top-management teams (71 percent) or the CEO (49 percent). Almost half of the companies further had CSR as a fixed topic on their top-management team's (TMT) meeting agenda to manifest its importance. In regards to the implementation and alignment of CSR, a broad majority of the corporations had formal procedures and decision-making structures. The deliverable outcomes and perceived opportunities were typically CSR activities evolving around winning more customer contracts, increased customer satisfaction, and easier connection between their product and service offerings and their customers' preferences. The corporations were also perceived by the marketplace as better partners to solve their customers' problems. Overall, they experienced increased attraction power regarding new business opportunities and in general conjectured to have reduced their overall market risks.

\section{MANAGERIAL IMPLICATIONS}

CSR is a promising addition to managers so as to improve their business through value-creation, survivability, and growth and improve their performance, as the majority of corporations approach CSR opportunities strategically. In summary, we recommend: (1) determine what is the strategic intent of CSR; (2) engage in CSR to gain a specific benefit; (3) approach CSR as an investment in intangible assets; (4) focus on a specific stakeholder category (ex. customers, suppliers, etc.); (5) decide how to communicate the CSR initiative; (6) look for positive spillover effects; (7) be sincere with your CSR engagement, and (8) design and manage the CSR decision-making process.

The first implication arises from our finding that corporations implementing CSR have a specific strategic intent. Mostly the intent is to gain competitive advantage, such as improved relationship with customers, suppliers and employees, reduce market risks and improve reputation. When designing a CSR program, managers should assess which of the four applied strategic intents best suits their current market standing (short term) and how it relates to a predicted future market standing (long-term). That is, should CSR be implemented to save some costs; to improve or strengthen the company's reputation; to reduce market risk or otherwise to support, enhance or create some competitive advantage? Once this choice is made the company can more easily define the ideal target stakeholder to support with specific CSR deliverables and in such a way better decide which CSR activities their program should entail.

Second, the evolutionary notion of CSR transforming from being a social concept (a charitable cause) into a corporate behavior and management philosophy, suggests strategic intent. Firms should engage in CSR with a selected strategic intent so that some specific benefit can result or be extracted from it. In other words, it has transformed from being perceived as a cost into becoming a strategic investment in intangible assets. This means that managers should not 
always expect distinctly related financial performance gains immediately. For instance, improved brand image, improved reputation and enhanced customer relationships can all lead to positive financial results, yet sometimes be difficult to codify as the exact source of financial results. Direct shortterm financial improvements should therefore be excluded as a reason to embark in CSR, since strategic CSR is a tacit and long-term concept and as such difficult to measure in terms of short-term quantifiable performance. The risk is that CSR as an otherwise promising strategic component is abandoned in the executive suite due to design problems regarding its measure. Measurement discussions can also lead to implementation of a CSR program that is measurable but not strategic or optimal in the eyes of the customers or supportive to the company's objectives -strategic or financial. Other management functions, such as marketing and research and development (R\&D), can also be difficult to quantify in terms of ROI (return on investment).

Third, companies now view CSR as part of the company's risk management and approache CSR like they approach other intangible investments. Companies are comparing CSR key performance indicators (KPIs) similarly to R\&D, branding or corporate culture, where profitability is a consequence of their deployment rather than its precursor. The R\&D concept is suitable since both CSR and R\&D embrace activities that have long lead times and embody willingness to experiment - and potential abandonment. This view improves the company's probability to turn a social problem into an economic opportunity. One such example is Microsoft's community college education program targeting schools in less fortunate areas, which improves IT education and possibly increases their future recruitment pool.

Fourth, the investigation into corporate behavior in the global marketplace regarding resource allocation toward CSR displays and demonstrates that firms focus on a specific stakeholder category. Since most firms lack both the resources and the interest to attempt satisfying every stakeholder category, they usually focus on customer expectations of good behavior manifested by supplier support programs. A customer focus makes employees feel more motivated toward their daily tasks. Stockholders will embrace the view of CSR as an investment, as long-term performance is increased. Also, institutional or ethical investors might further become more interested in the company due to strengthened legitimacy and reputation among market analysts. By engaging in CSR from a strictly strategic win-win-win perspective (that is, for the company, the stockholders and the CSR target stakeholder) companies report improved preference of their products and services by their customers. As a result, implementation of strategic CSR is an addition to other components supporting revenue and market share growth.

Fifth, past research illustrates a direct relationship between the amount spent in marketing dollars (for example in the form of advertising) and sales revenue; this is not the case for CSR marketing. The marketplace simply expects and demands product-related marketing and communication to vouch for the value and quality of the products. Product and service related marketing is a highly proactive "push" approach to connect with existing and prospective customers. In contrast, to be strategic, CSR must be "hidden but easily found." If a corporation markets their CSR efforts in the same fashion as their products and services, it is counterproductive and at best perceived as solely selfserving. Sub-optimally planned CSR communication might not benefit the corporation but instead risk skepticism and cynicism among their customers and investors, which defeats the communication purpose. Instead, successful strategic CSR communication is made available (timing) in a reactive and introverted fashion (design), where the marketing of a corporation's CSR efforts should be "pulled" from the corporation by interested parties. In case of media or activist attention regarding some perceived less-thanfavorable behavior (true or not) CSR-related communication should follow the event causing the disturbance instead of preceding it. In other words, in such situations it is practice among the CSR top-performing corporations to launch CSR communication in a reactive and pre-emptive way. Not that they are "so good," but that they will never behave badly.

Sixth, corporations with a high level of strategic intent had a high rank of CSR and high performance. A high ranking of CSR provides important positive side effects in addition to the other potential benefits in the form of spillover effects. The creation of spillover effects emerges from the customers' view that a reputable company is both a company of higher quality and a company that provides better CSR. The spillover effects are shared by both external market participants (analysts, investors, customers and suppliers) and internal immediate stakeholders (employees, managers and stockholders). High CSR corporations attract more talented employees without paying higher than industry average salaries and complete their recruitment processes faster.

Seventh, a company may face repercussions if they are insincere with CSR initiatives. Our survey suggested that companies require a sincere approach to their CSR commitments and programs. Some corporations report that an employee who believes he or she is working for a reputable company but finds the employer behaving irresponsibly, can feel betrayed and become upset or de-motivated. This insincerity can lead to losing valuable staff members, disrupting group dynamics, increasing departmental frustration, confusion or even lost supplier and customer relationships. Managers who elect to pursue the CSR opportunity are therefore recommended to engage in their CSR efforts with sincerity at the operational level during implementation.

Finally, a majority of the corporations assign CSR decisionmaking to their top management team (TMT), which usually is supported by a CSR committee consisting of cross-functional staff members. In contrast, companies that had invested in a dedicated CSR executive reported to assigning him or her autonomous decision-making in only one-third of the companies. CSR was a strategic initiative for the TMT, as CSR was a fixed topic on their meeting agenda. The organizational design for CSR responsibility should be for either a dedicated CSR executive, or to some existing manager (for example the vice president of strategy or branding or the human resources manager) to ensure that someone is responsible and accountable for CSR initiatives.

We conclude with rephrasing the famous words of David Packard, founder of Hewlett-Packard Co., who reflected upon customer attraction and retention: "Marketing is too 


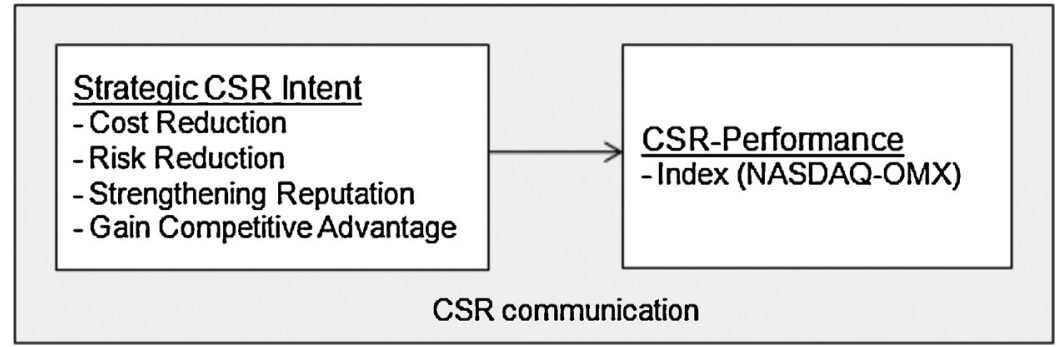

Figure 1 The Strategic Intentions to Engage in CSR.

important to be left to the marketing department." CSR has become an imperative for firms that are competing globally, due to the ease and movement of information as good new travels quickly, and bad news even faster. CSR and strategy are intertwined, and to maximize the strategic CSR potential, an integrated approach will be required. This intangible asset is too important to be left to the CSR department, but integrated throughout the firm and their strategy.

To order reprints of this article, please e-mail reprints@elsevier.com 


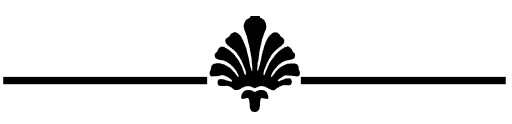

\section{SELECTED BIBLIOGRAPHY}

For information about making the business case with CSR, see A. B. Carroll \& K. M. Shabana, "The Business Case for Corporate Social Responsibility: A Review of Concepts, Research and Practice," International Journal of Management Reviews, 2010, 12(1), 85-105; J. Kang, “The Relationship Between Corporate Diversification and Corporate Social Performance," Strategic Management Journal, 2013, 34(1), 94-109; X. Luo \& C. B. Bhattacharya, "The Debate over Doing Good: Corporate Social Performance, Strategic Marketing Levers, and Firm-Idiosyncratic Risk," Journal of Marketing, 2009, 73, 198-213; and P. Schreck, D. van Aaken, \& T. Donaldson, "Positive Economics and the Normativistic Fallacy: Bridging the Two Sides of CSR," Business Ethics Quarterly, 2013, 23(2), 297-329.

For information on CSR in general, see J. L. Walls, P. Berrone \& P. H. Phan, "Corporate Governance and Environmental Performance: Is There Really a Link?" Strategic Management Journal, 2012, 33(8), 885-913; J. S. Harrison, D. A. Bosse \& R. A. Phillips, "Managing for Stakeholders, Stakeholder Utility Functions, and Competitive Advantage," Strategic Management Journal, 2010, 31(1), 58-74; KPMG, "International Survey of Corporate Responsibility Reporting," KPMG, 2011, 1(1). A. McWilliams \& D. Siegel, "Corporate Social Responsibility: A Theory of the Firm Perspective," The Academy of Management Review, 2001a, 26, 117-127; and T. Melo, \& A. Garrido-Morgado, "Corporate Reputation: A Combination of Social Responsibility and Industry," Corporate Social Responsibility and Environmental Management, 2012, 19(1), 11-31.

For information about the link between strategy and CSR, see B. Cheng, I. Ioannou \& G. Serafeim, "Corporate Social Responsibility and Access to Finance," Strategic Management Journal, 2013, doi: 10.1002/smj.213; K. Bondy, J. Moon \& D. Matten, "An Institution of Corporate Social
Responsibility (CSR) in Multi-National Corporations (MNCs): Form and Implications," Journal of Business Ethics, 2012, 3(2), 281-299; and B. Lev, C. Petrovits \& S. Radhakrishnan, "Is Doing Good Good for You? How Corporate Charitable Contributions Enhance Revenue Growth," Strategic Management Journal, 2011, 31(2), 182-200.

For information about CSR-derived financial and other performance, see T. Wang \& P. Bansal, "Social Responsibility in New Ventures: Profiting From a Long-Term Orientation," Strategic Management Journal, 2012, 33(10), 11351153; M. Porter \& E. Kramer, "Strategy \& Society. The Link Between Competitive Advantage and Corporate Social Responsibility," Harvard Business Review, 2006, 84 (December), 1-14; M. L. Barnett \& R. M. Salomon, "Does It Pay To Be 'Really' Good? Addressing The Shape Of The Relationship Between Social And Financial Performance," Strategic Management Journal, 2012, 33(11), 1304-1320; and D. J. Wood, "Measuring Corporate Social Performance: A Review," International Journal of Management Reviews, 2010, 12(1), 50-84.

For information about CSR-related marketing and communication, see X. Luo \& C. B. Bhattacharya, "The Debate over Doing Good: Corporate Social Performance, Strategic Marketing Levers, and Firm-Idiosyncratic Risk," Journal of Marketing, 2009, 73, 198-213. A. McWilliams \& D. S. Siegel, "Creating and Capturing Value," Journal of Management, 2011, 37(5), 1480-1495; and S. Ramchander, R. G. Schwebach \& K. I. M. Staking, "The Informational Relevance of Corporate Social Responsibility: Evidence from DS400 Index Reconstitutions," Strategic Management Journal, 2012 33(3), 303-314; and T. Wagner, R. J. Lutz \& B. A. Weitz, "Corporate Hypocrisy: Overcoming the Threat of Inconsistent Corporate Social Responsibility Perceptions," Journal of Marketing, 2009, 73, 77-91.

Lars Isaksson (Ph.D. in management, M.B.A., and M.I.B.) is a lecturer of strategy, strategic management and international business in the School of Business at Bond University, Australia. He studies global business strategy and corporate social responsibility (CSR) in relation to the strategic management field in multi-national companies and the economics of CSR. His research focuses on the effects of corporate behavior or citizenship, and how organizations can improve their performance through reputation building and strategy derived brand- and market performance. Prior to his Ph.D., Isaksson worked ten years in the global IT arena as a solution sales and marketing manager providing supply chain improvement technologies (mobile computing, RFID) to companies such as CocaCola, ABB, Toyota, Carlsberg and IBM. His international industry exposure spans more than fifty countries in Europe, North and Central America, the Middle East and Asia-Pacific (Strategy \& International Business, Bond University, School of Business, Robina 4226, Queensland, Australia. Tel.: +61 075595 3356; fax: +61 0432596 404; e-mail: lisaksso@bond.edu.au).

Tim Kiessling has a C.P.A., C.I.A., and an M.B.A. in finance and completed a Ph.D. in marketing/management with a concentration in global business strategy from the University of Oklahoma. He has published over 30 articles in refereed journals such as the Journal of World Business, International Marketing Review, International Journal of Human Resource Management, IJPDLM, Organizational Dynamics and Journal of Business Strategies. His research interests focus on global strategic management, top management teams, international 
strategic human resource management and mergers and acquisitions (Business Strategies, Bilkent University, Turkey; e-mail: kiessling@bilkent.edu.tk).

Michael Harvey is Distinguished Chair of Global Business in the School of Business Administration at the University of Mississippi. Harvey has been an active researcher and consultant for global organizations over the last 30 years (Distinguished Chair of Global Business, University of Mississippi, USA; Global Business, Bond University, Australia; e-mail: mharvey@bus.olemiss.edu). 